Vol. 4, No. 3, 2019

\title{
ANALYSIS OF TECHNOGENIC LOAD ON THE AIR BASIN OF INDUSTRIAL AND URBAN AGLOMERATIONS IN UKRAINE
}

\author{
Angelina Chugai, Yuliia Bazyka \\ Department of Environmental Science and Environmental Protection, \\ Odessa State Environmental University, \\ 15, Lvivska Str., Odessa, 65016, Ukraine \\ avchugai@ukr.net
}

https://doi.org/10.23939/ep2019.03.135

Received: 21.07 .2019

(C) Chugai A., Bazyka Y., 2019

\begin{abstract}
The influence of the main sources of anthropogenic pollution on the state of the air of some industrial and urban agglomerations in Ukraine is examined in the paper. The level of anthropogenic load on the air basin from the stationary and mobile sources of pollution is assessed, their contribution to the overall level of air pollution is determined.
\end{abstract}

Key words: industrial and urban agglomeration, anthropogenic load, module of technogenic load.

\section{Introduction}

Significant volumes of pollutant emissions from the stationary and mobile sources into the air in the regions of Ukraine are the cause of formation of high level of atmospheric pollution. This problem is especially acute in large industrial and urban agglomerations (IUA). The condition of the air basin on the one hand depends on the quantity and technological characteristics of industrial objects and on the other hand on the park of motor transport in the regions.

In the paper [1] the estimation of technogenic load on the IUA of the North-Western Black Sea Region (Odesa, Mykolaiv and Kherson regions) was performed. In this paper some of the IUAs of Ukraine, namely, the Dnipropetrovsk, Kharkiv, Lviv and Kyiv regions are considered. The level of air pollution of these IUAs in recent years by the values of the comprehensive air pollution index (CAPI) is characterized by the categories from "clean" to "heavily contaminated". That is why the definition of the main sources of pollution and the assessment of the man-made load on the air basin is an urgent and necessary task.

\section{Theoretical part}

Materials of Regional reports, Environmental passports and regional statistical reporting on the atmospheric air emissions in the regions as well as the data of monitoring observations for 2013-2017 were used as the input data in the work.

The paper uses statistical and comparative analysis methods. To assess the level of air pollution, the air pollution index (API) is considered.

API is calculated as a separate admixture by the formula:

$$
I=\left(\frac{\bar{q}}{M P C}\right)^{C_{i}}
$$

where $M P C$ is the maximum permissible concentration; $C i$ is a constant that acquires values of $1.7 ; 1.3 ; 1.0 ; 0.9$ respectively for the $1^{\text {st }} ; 2^{\text {nd. }} ; 3^{\text {rd }}$ and $4^{\text {th }}$ grade of the substance harm and allows you to bring the degree of harmfulness of the i-th substance to the degree of dioxide sulfur harm.

It is believed that if $A P I \leq 1$, the quality of the air by the content of a separate pollutant meets sanitary and hygiene requirements.

Comprehensive API (CAPI) is a quantitative description of the air pollution level formed by $n$ substances which are present in the atmosphere of the city. CAPI is calculated by the formula:

$$
I_{n}=\sum_{i=1}^{n} I_{i} \text {. }
$$

For the integral estimation of the air pollution level with the help of the CAPI, one can use the values of individual air pollution indexes of the five pollutants for which these values are the largest. That is

$$
I_{5}=\sum_{i=1}^{5} I_{i} .
$$


The value of $I 5$ less than 2.5 corresponds to clean atmosphere; from 2.5 to 7.5 - poorly contaminated; from 7.6 to 12.5 - contaminated; from 12.6 to 22.5 heavily polluted; from 22.6 to 52.5 - highly polluted; more than 52.5 - extremely polluted atmosphere [2].

One of the indicators of the total technogenic load on the territory of the IUA of Ukraine is a module of technogenic load $\left(M_{T}\right)$, which is defined as a sum of weight units of all types of waste (solid, liquid, gaseous) of industrial, agricultural and communal objects for the time interval of 1 year, assigned to the area of the administrative district or region within which these objects are located, and is measured in thousand $t / \mathrm{km}^{2}$ per year [3]. Technogenic load in the majority of cases is represented by a significant list of indicators characterizing the impact on the individual components of the environment, including the air basin and is the emission of air pollutants into the atmosphere by the stationary and mobile sources of pollution (ths. tons/year). In the work the estimation of technogenic load level on the air basin is made based on the calculation of a module of technogenic load on the air basin $\left(M_{A B}\right)$, which is defined as the amount of emissions of air pollutants into the atmosphere in thousand $\mathrm{t} / \mathrm{km}^{2}$ per year.

\section{Results and discussion}

Estimation of the air pollution level. The main sources of air pollution in the Dnipropetrovsk region are industrial objects [4]. The regional center - the city of Dnipro is also under significant anthropogenic pressure. According to [5], the city of Dnipro is among the most polluted cities in Ukraine. In the paper [6], the authors determined the air pollution level of the city of Dnipro and technogenic load on the region.

Thus, the pollution emissions from the district stationary sources are almost 4 times higher than the emissions from the mobile ones. A slight general trend towards emission reduction in 2014-2016 is noted. The main polluters of the environment are metallurgical, mining and power companies. The most environmentally dangerous types of economic activity are mining of metal ores, electricity generation, iron, steel and ferroalloy industries [4].

Observations on the air quality in the city of Dnipro according to [7-11] in different years were performed at different amounts of pollutants (from 3 to 9). Fig. 1 shows the results of calculation of the CAPI of the city of Dnipro. It should be noted that in 2013 in the calculation only 3 substances were present. Over the entire period of the study an increase in the CAPI in the city of Dnipro was noted. Dust, nitrogen dioxide and formaldehyde fall into the substances for which the air quality constantly does not meet the standards. In 2013-2016, the level of air pollution in the city of Dnipro can be classified as "contaminated", in 2017 - as "heavily polluted".

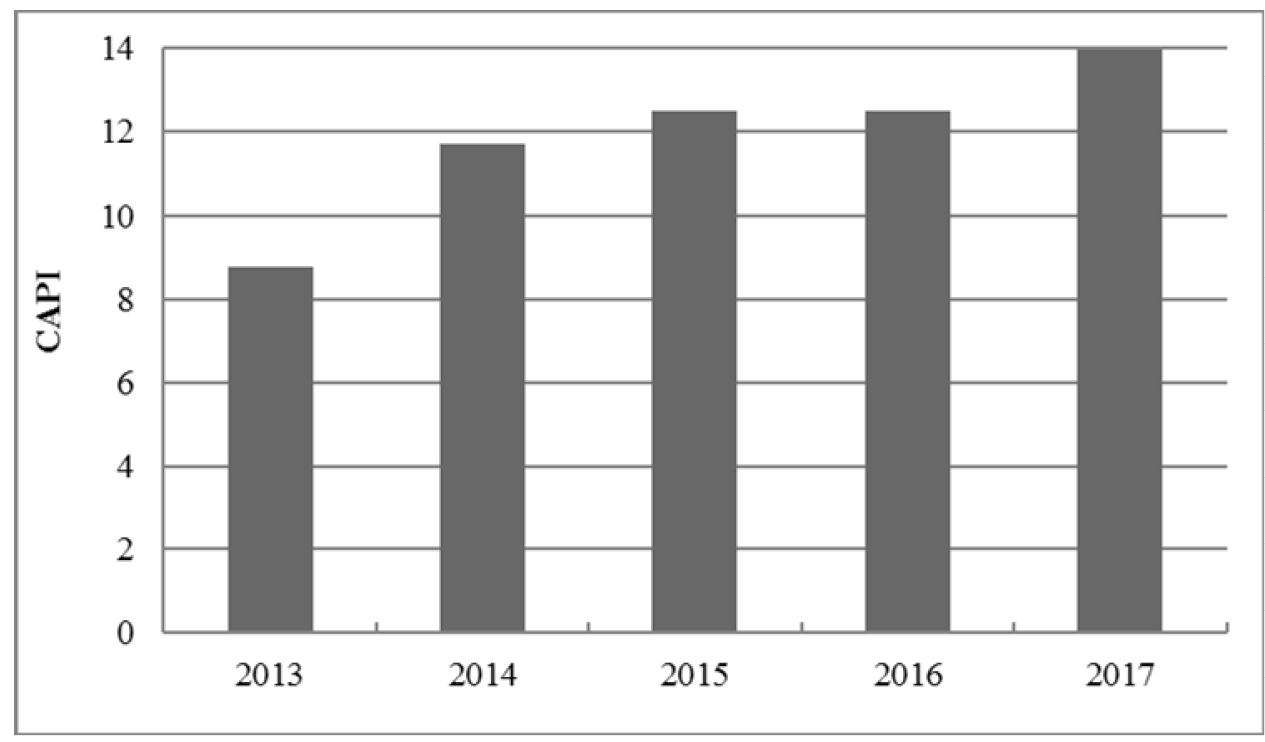

Fig. 1. Dynamics of change of the CAPI of the Dnipro city in 2013-2017

The Kharkiv region is a large industrial center of Ukraine, where almost all types of economic activity are represented. In the period from 2010 to 2014, the volume of emissions from the stationary sources dominated the mobile ones. The main pollutants of the atmosphere of the region among the stationary sources are enterprises of heat and power and oil and gas industry [12].
The assessment of the air quality was carried out for the city of Kharkiv. Observations in the city according to the data [13-17] are carried out at 10 stationary posts at concentrations for 10 pollutants. The only substance which exceeds the standards is carbon monoxide. In general, the highest values of the $A P I$ were noted for such substances as dust, carbon 
monoxide, nitrogen dioxide, phenol, formaldehyde and in some years soot.

Fig. 2 shows the dynamics of change of the CAPI in Kharkiv. As you can see, the maximum value of the CAPI is due in 2015. In general, there is an increase in the air pollution level in the city of Kharkiv. In 2013, the pollution level is characterized as "clean", in other years "poorly contaminated" atmosphere.

In the Lviv region, the overall level of air pollution is formed equally by emissions from the stationary and mobile sources of pollution. The largest volumes of pollutant emissions into the air are provided by the enterprises supplying electricity, as well as stone and brown coal mining.

Observations on the air quality were carried out in Lviv. The data from [18 to 22] were used for estimation. Fig. 3 shows the schedule of change of the CAPI in Lviv. The analysis of the above figure shows that during the study period an increase in the value of CAPI was observed due to the increase, first of all, of formaldehyde concentrations in the air by more than 2 times.

The level of air pollution in Lviv can be categorized as "poorly contaminated".

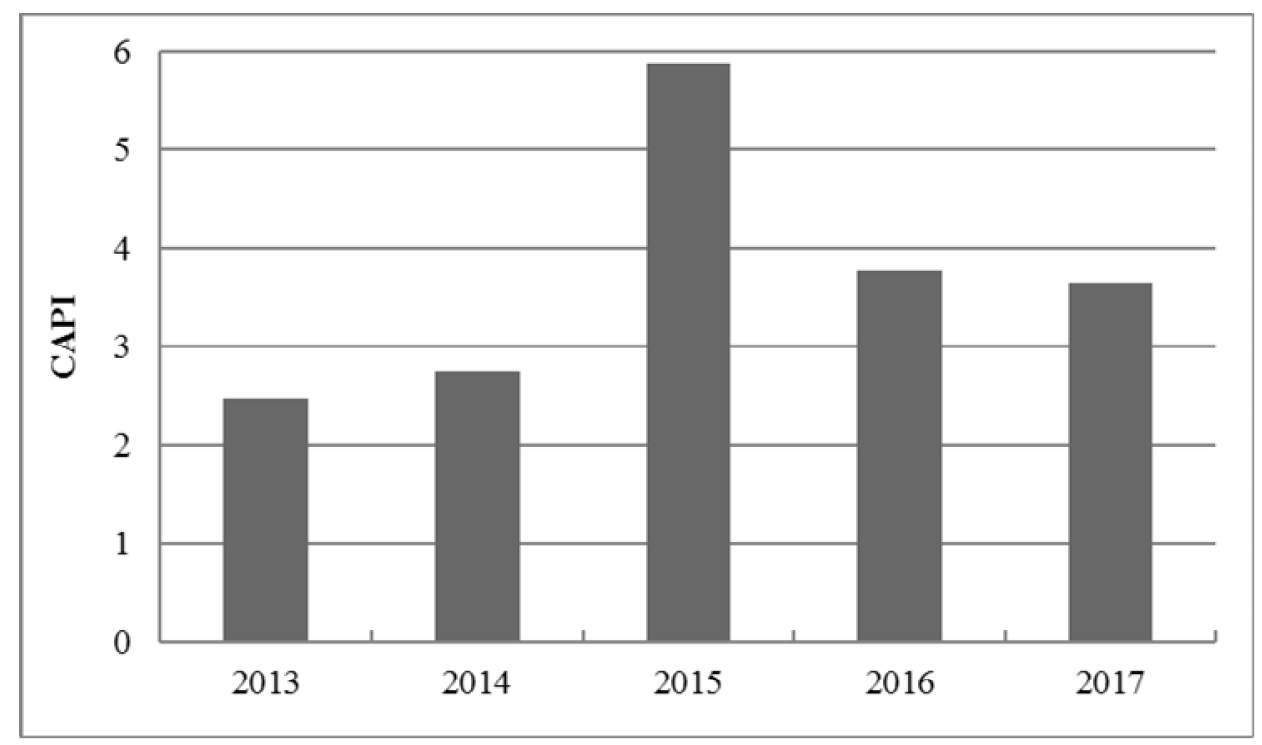

Fig. 2. The dynamics of change of the CAPI in Kharkiv in 2013-2017

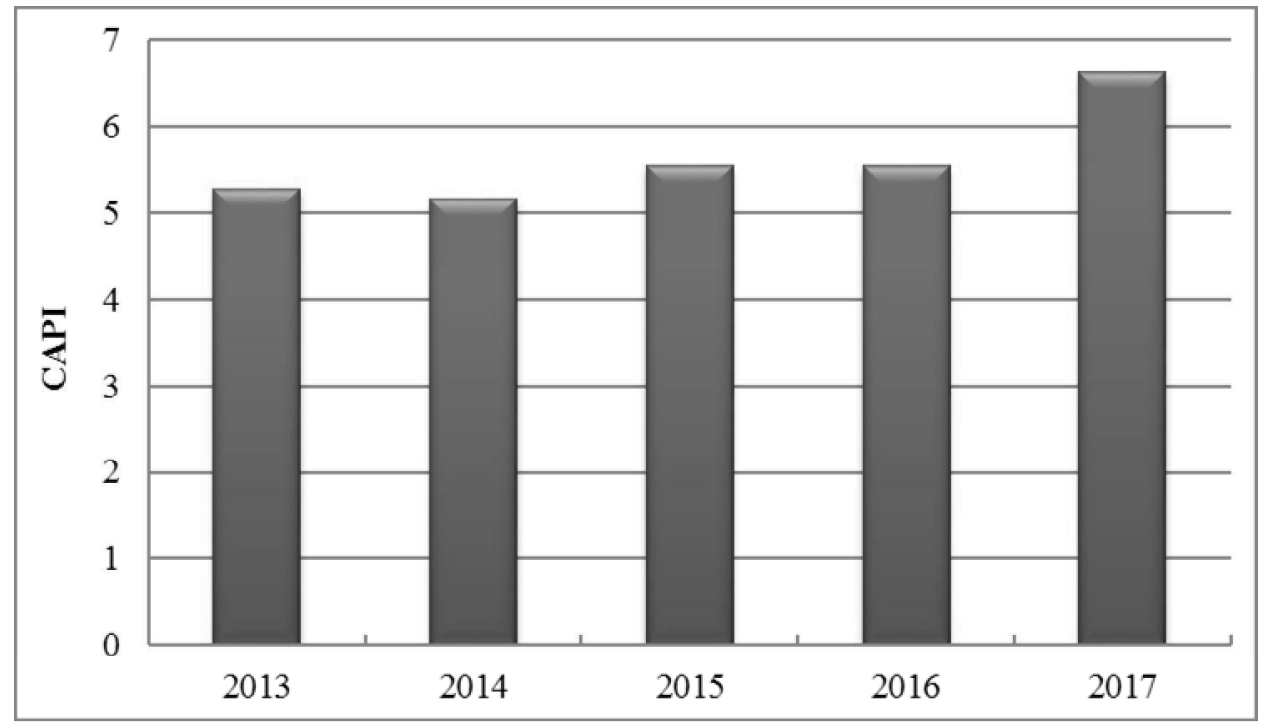

Fig. 3. The value of the CAPI in Lviv in 2013-2017

According to [5] the Kyiv region and, first of all, Kiev are among the most contaminated regions in Ukraine. The main contribution to the air pollution is made by the enterprises of the thermal power engineering. Transport and enterprises of housing and communal services are also the biggest polluters [23]. 
Fig. 4 shows a schedule of change of the CAPI in Kyiv. The analysis of the figure shows that the level of air pollution has not undergone significant changes. For the whole period of observations, it is characterized by a single category - "contaminated" atmosphere.

Based on the obtained data, we carried out a comparative analysis of the level of pollution of the individual IUAs of Ukraine. Fig. 5 shows a schedule of changing the CAPI of IUAs which were discussed above. As you can see, a maximum level of air pollution is observed in the city of Dnipro. Kyiv ranks second. A minimum level is noted in Kharkiv, although as mentioned above, it is a large industrial center of Ukraine with developed almost all industries.

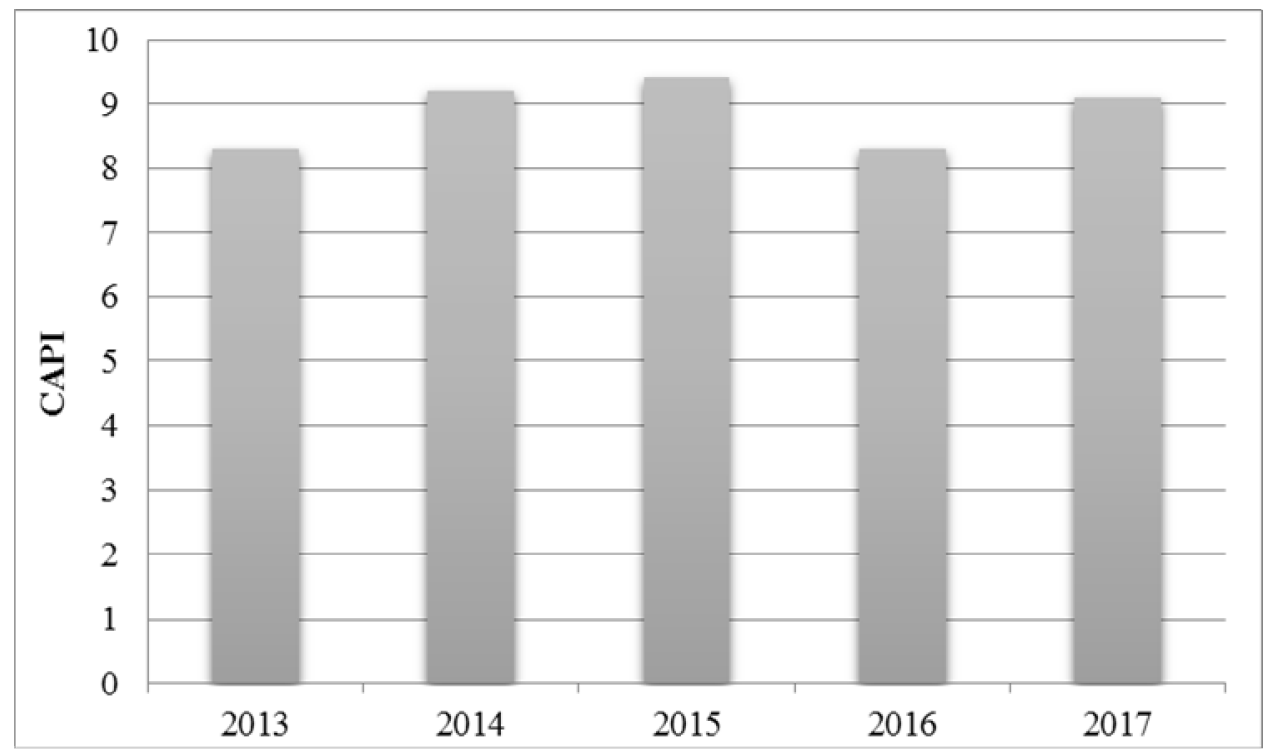

Fig. 4. The value of the CAPI in Kyiv in 2013-2017

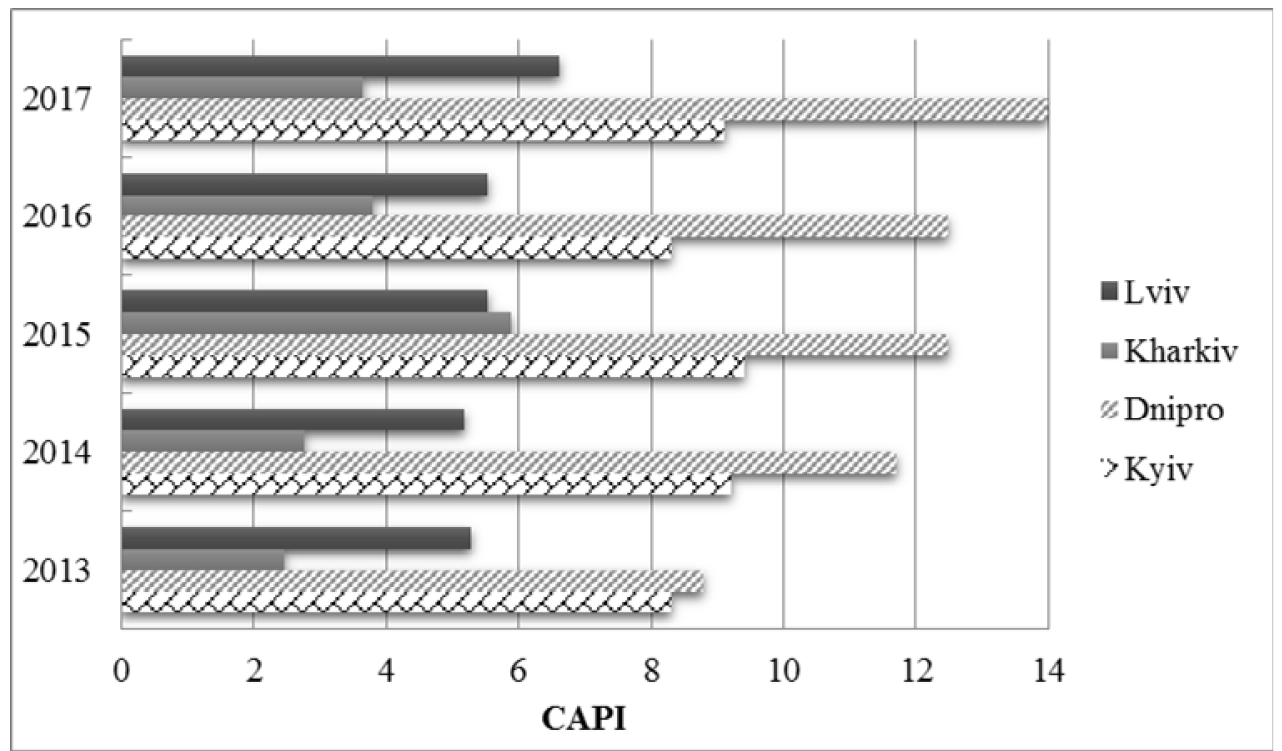

Fig. 5. Values of the CAPI of individual IUAs of Ukraine in 2013-2017

Assessment of technogenic load level. The calculation of the $M_{A B}$ indicator for the Dnipropetrovsk region was completed for 2013 2016. The level of anthropogenic pressure on the Dnipropetrovsk region by the emissions from the stationary and mobile sources, as well as on the city of Dnipro by the emissions from the stationary sources was estimated. The information on the area of the region as a whole and of the city of Dnipro was used for calculation [24].

Fig. 6 shows the dynamics of change of the $M_{A B}$ indicator for the Dnipropetrovsk region and the city of Dnipro. As can be seen, in the region the indicator of the $M_{A B}$ from the stationary sources considerably 
exceeds that of the mobile ones. And this is quite logical taking into account the volumes of the emissions from the relevant sources of pollution. If we compare the value of the $M_{A B}$ from the stationary sources, one can see that the level of technogenic load in the city of Dnipro exceeds the corresponding one in the region. This indicates a significant level of technogenic load on the Dnipro air basin from the stationary sources. At the same time, as it was shown by the analysis, the amount of emissions from the stationary sources in the region compared with the city of Dnipro is an order of magnitude higher, and the area of the region is two orders of magnitude. It should also be noted that there is some reduction in the technogenic load level on the airspace of the Dnipropetrovsk region as a whole.

The estimation of technogenic load on the air basin of the Kharkiv region was carried out according to the data of the emissions from the stationary and mobile sources in the region, as well as for Kharkiv according to the data of the emissions from the stationary sources, taking into account the information of the area of the region and the city.

Fig. 7 shows the dynamics of change of the $M_{A B}$ indicator for the Kharkiv region and the city of Kharkiv. The analysis shows that in Kharkiv, over the years, the load from the stationary sources decreases in comparison with the mobile ones. If we compare the level of anthropogenic pressure from the stationary sources in the region and in the city of Kharkiv, then the $M_{A B}$ index for the city of Kharkiv is 2 to 3 times higher than that for the Kharkiv region.
Separate results of the estimation of technogenic load on the air basin in the Lviv region are given in the work [25]. The value of the $M_{A B}$ (Fig. 8) in the region as a whole decreased somewhat due to the decrease in this indicator for the stationary sources. As in other regions, from 2016 there is no official data on the volumes of the emissions from the mobile sources. But, as noted above, the contribution of the emissions from the stationary and mobile sources in the Lviv region is almost the same. And taking into account the obtained data of the indicator for the stationary sources, it is possible to accept in general for the Lviv region that the emissions from the mobile sources in 2016 were at the level of 2015, namely 0.009. The level of technogenic load in Lviv from the stationary sources is an order of magnitude higher than the corresponding one in the region. The maximum value of the $M_{A B}$ indicator was noted in Lviv in 2015 .

To calculate the $M_{A B}$ indicator for the Kyiv region, the data of the pollutant emissions from the stationary and mobile sources of pollution given in [23, 26] were used. Fig. 9 shows the dynamics of change of the $M_{A B}$ in 2013-2017. In the region the level of technogenic load from the mobile sources is much higher than that of the stationary ones. In general, the study period is noted reducing the load from both sources of pollution. Similarly as in Lviv, the level of anthropogenic pressure from the stationary sources is an order of magnitude higher than the corresponding one in the region and during the research period there were no significant changes.

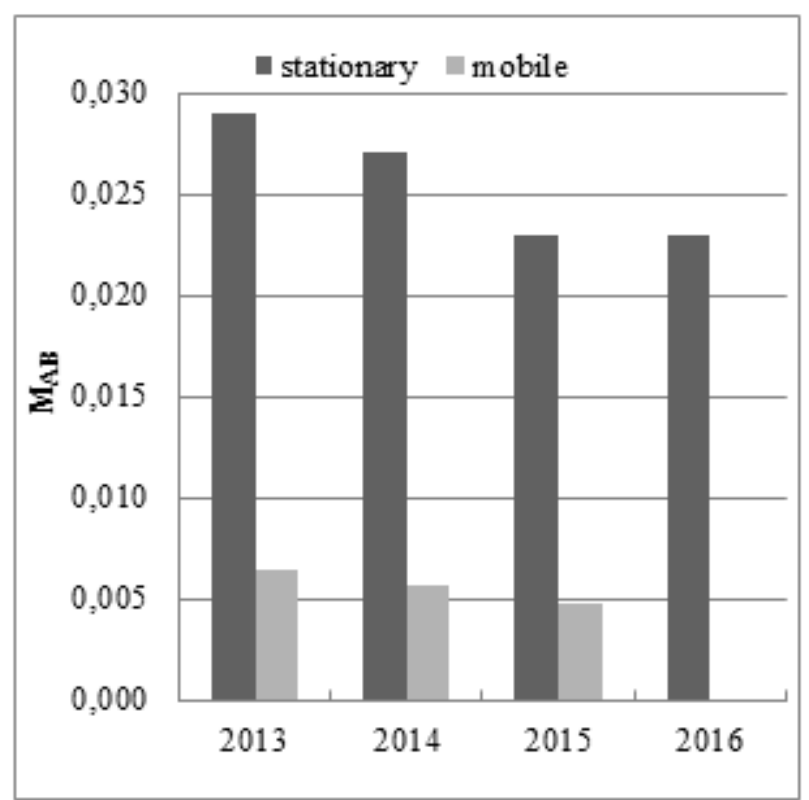

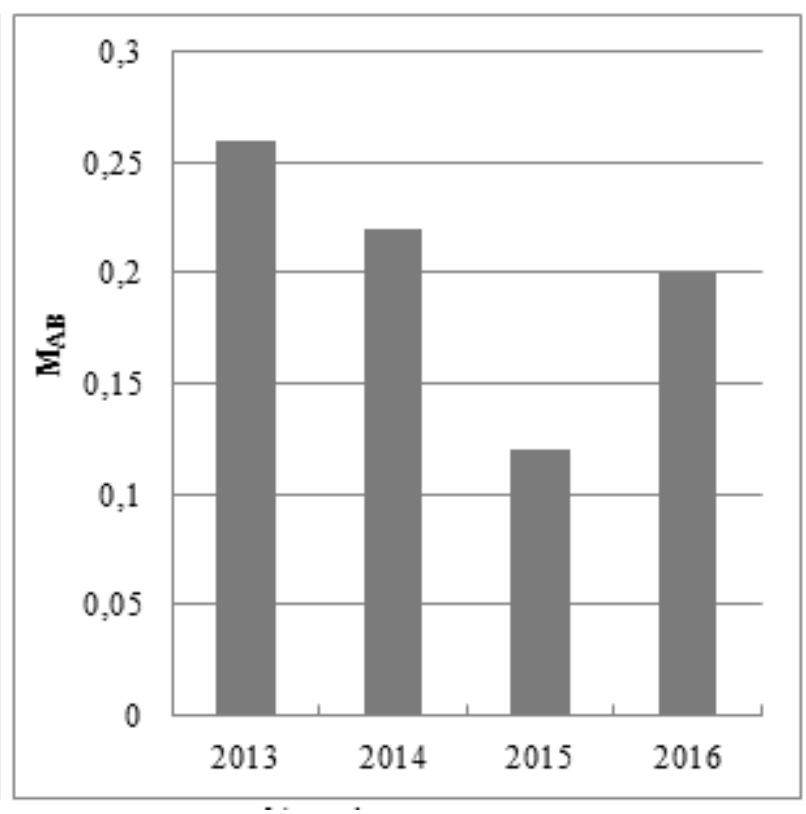

b stationary sources

Fig. 6. The dynamics of the change of $M_{A B}$ in the Dnipropetrovsk region (a) and the city of Dnipro (b) in $2013-2016$ 

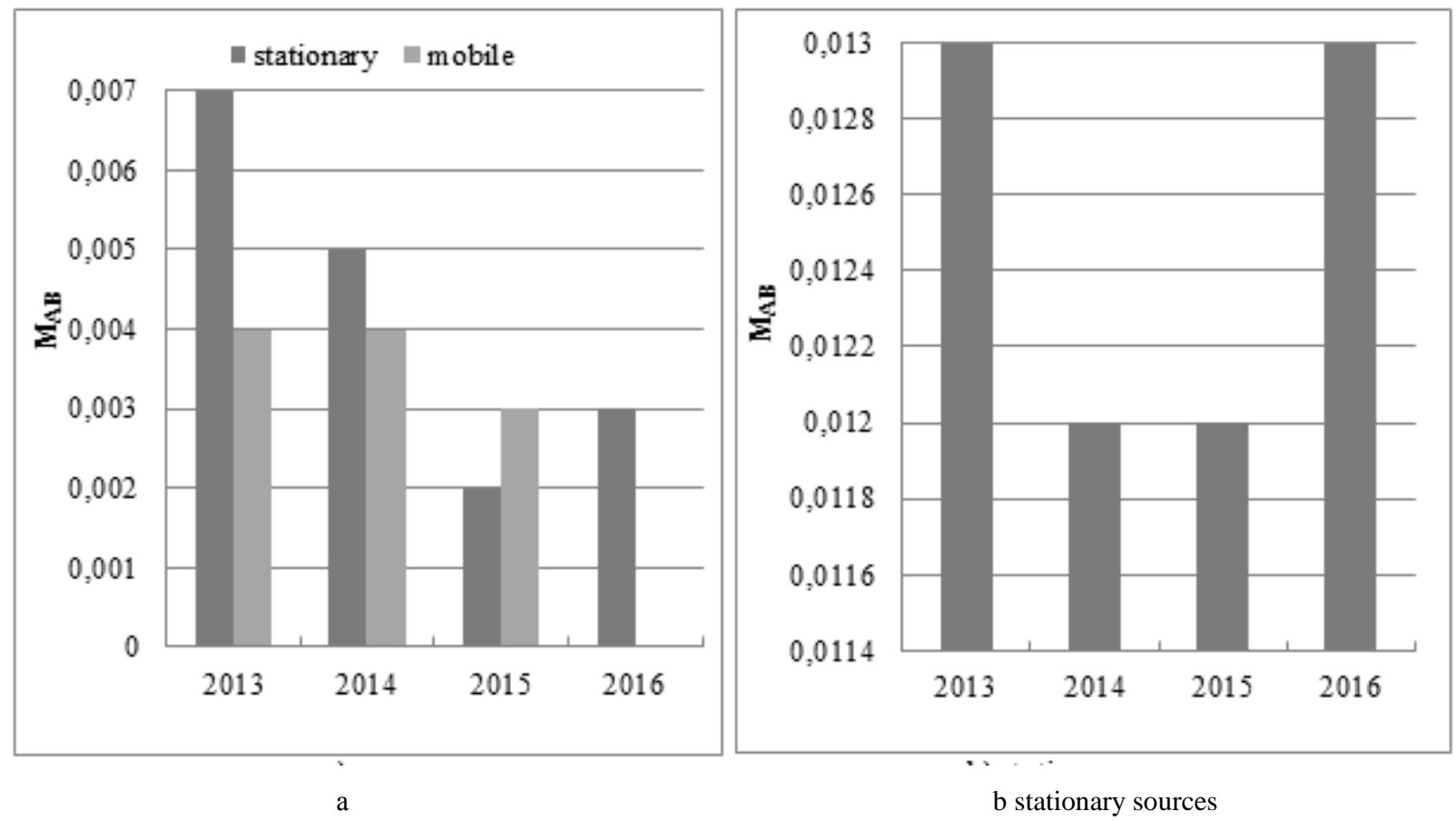

Fig. 7. Dynamics of change of the $M_{A B}$ in the Kharkiv region (a) and Kharkiv (b) in 2013-2016

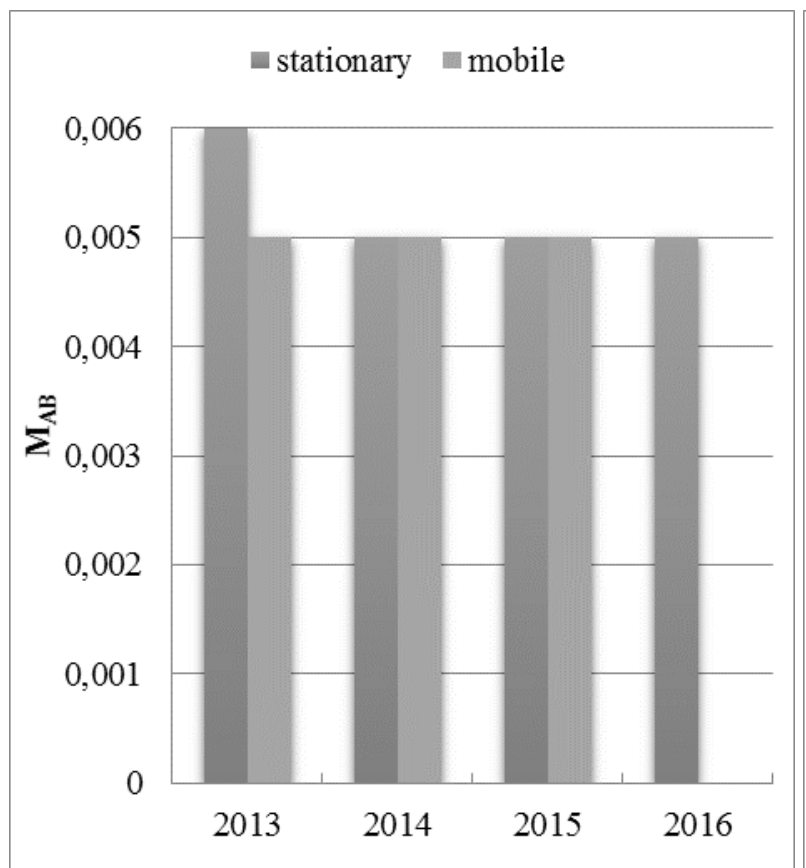

a

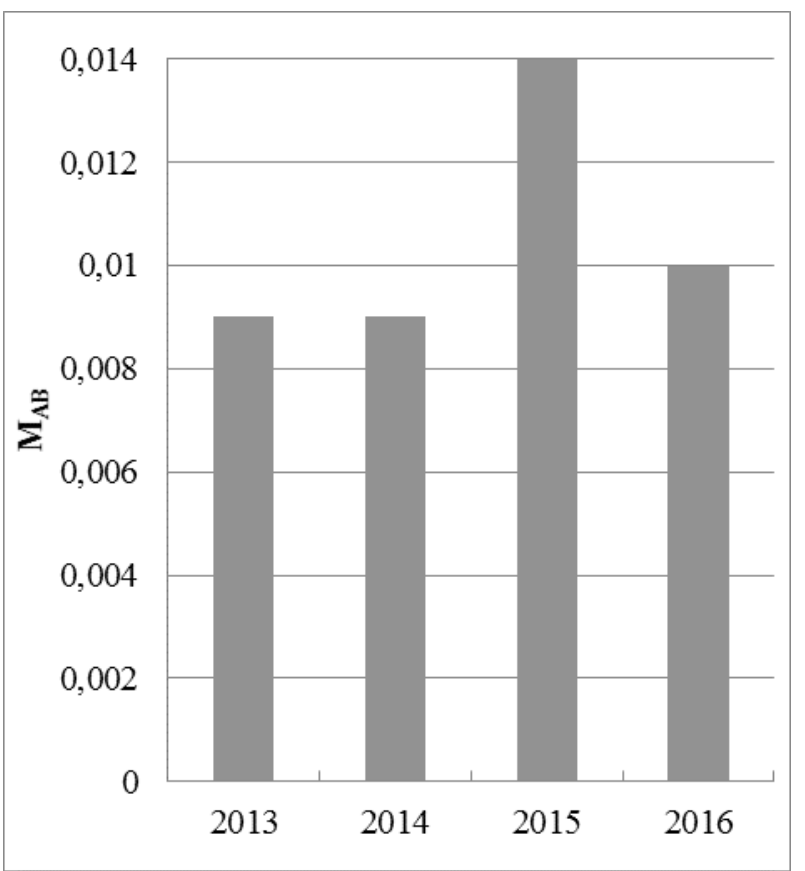

b stationary sources

Fig. 8. Dynamics of change of the $M_{A B}$ in the Lviv region (a) and Lviv (b) in 2013-2016

The comparative analysis of the level of anthropogenic pressure on the research regions shows that the maximum load is observed in general in the Dnipropetrovsk region. The value of the $M_{A B}$ is an order of magnitude higher than that of other areas. If we consider the level of technogenic load on the IUA (Fig. 10), the city of Dnipro is under the greatest pressure. As it was noted above, the air pollution level among the IUAs is also maximized in the city of Dnipro. The cities of Lviv and Kharkiv are characterized by relatively similar values of the $M_{A B}$ indicator. Unfortunately, the data received for the IUA do not reflect the situation as a whole, since the information about the volumes of pollutant emissions from the mobile sources is almost absent. But it can be noted that for the city of Dnipro the stationary sources of pollution are predominant. 


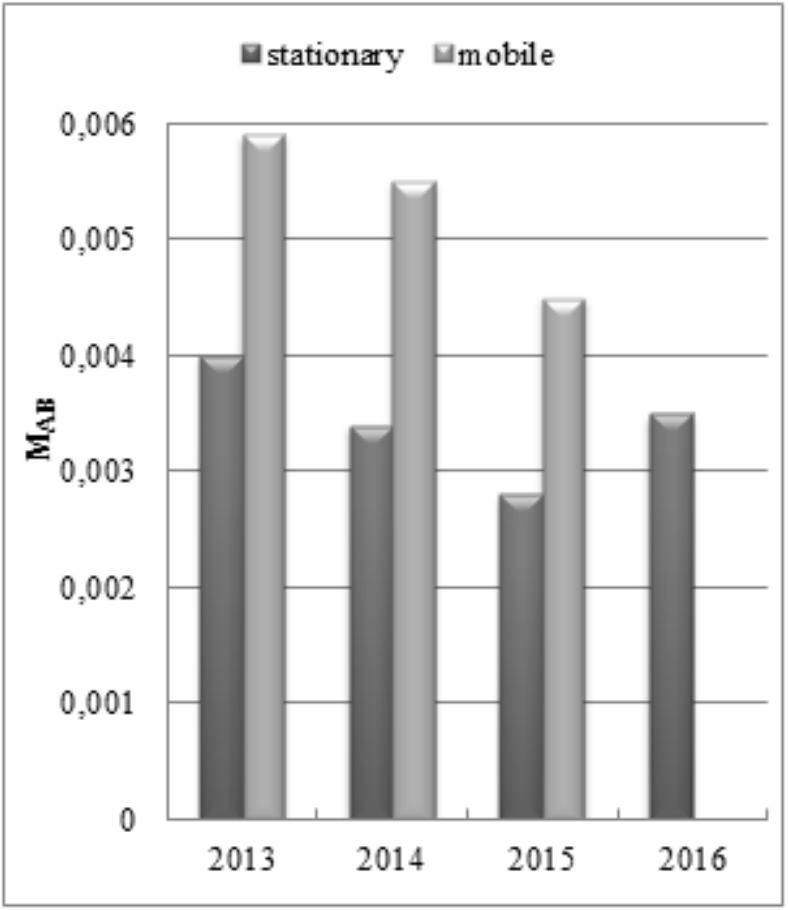

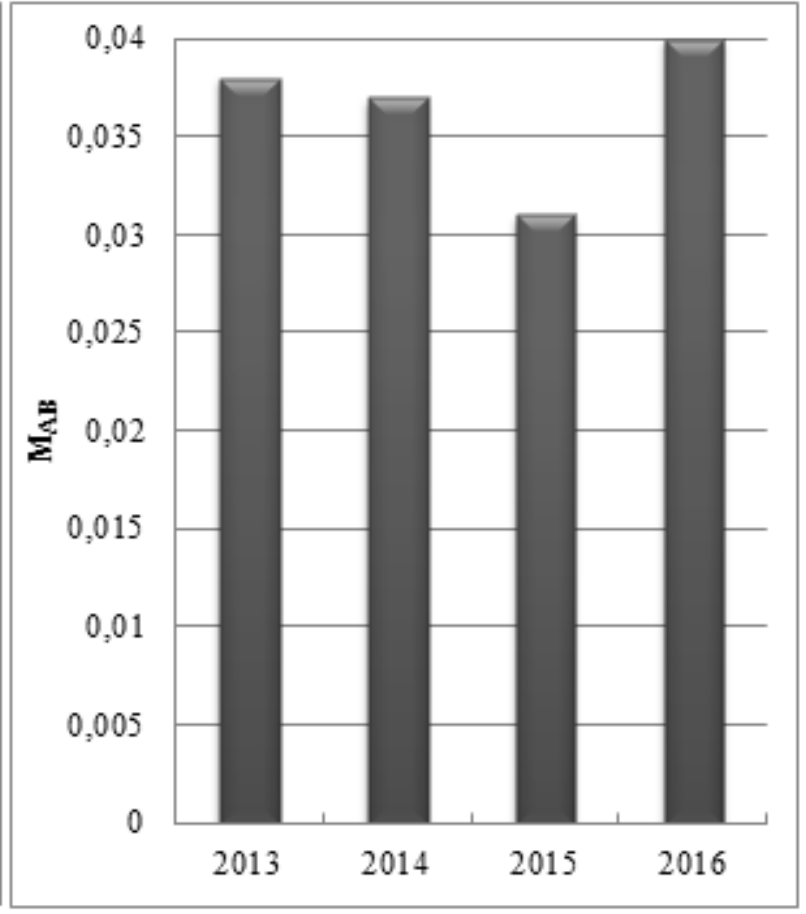

b stationary sources

Fig. 9. Dynamics of change of the $M_{A B}$ in the Kyiv region (a) and Kyiv (b) in 2013-2016

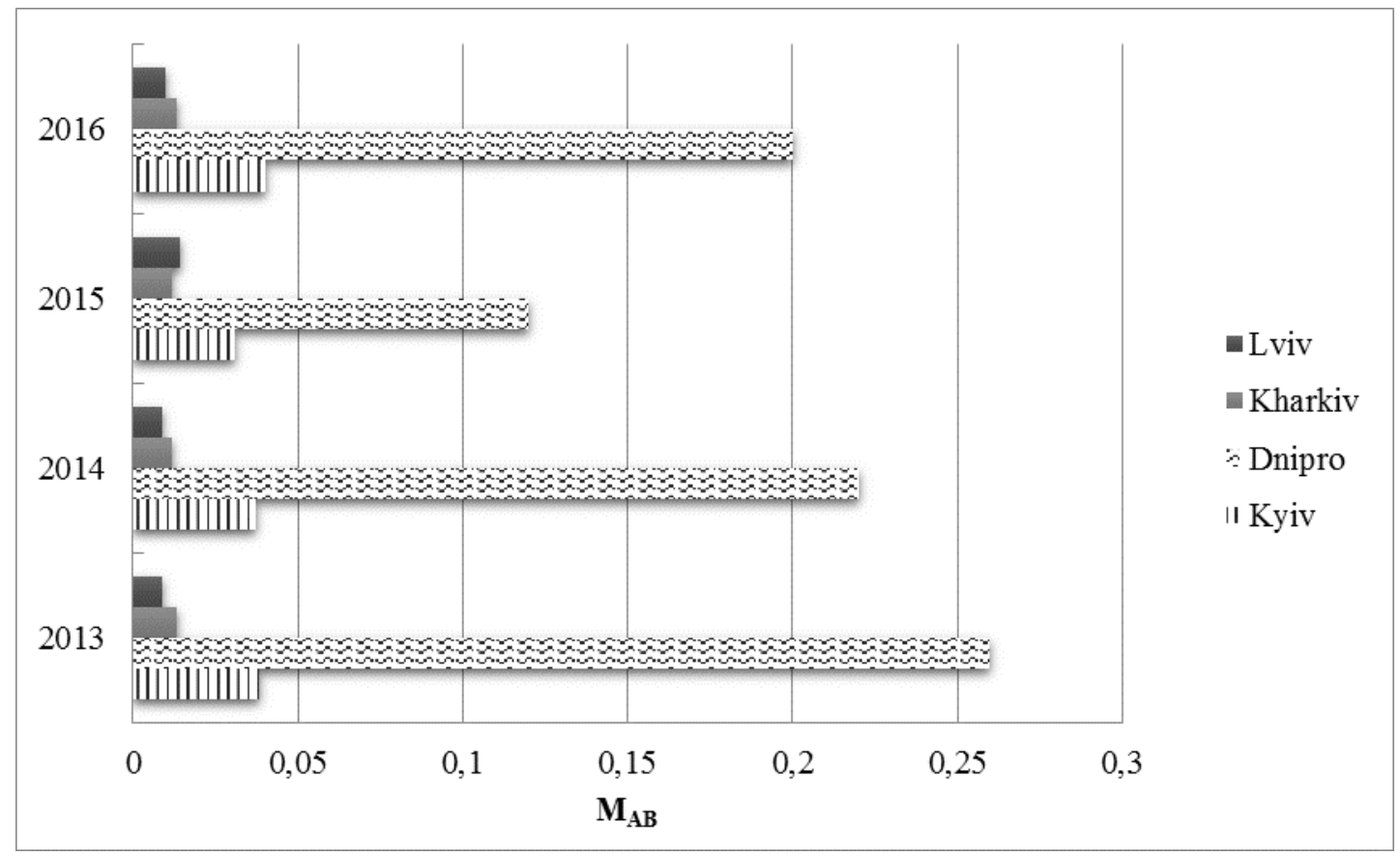

Fig. 10. Dynamics of change of the $M_{A B}$ of individual IUAs in Ukraine in 2013-2016 (from the stationary sources)

\section{Conclusions}

As a result of the research, the following conclusions can be made:

- In the city of Dnipro permanent excess of norms is noted for the content of dust, nitrogen dioxide and formaldehyde. The level of air pollution is characterized by the categories "contaminated" - "heavily polluted" atmosphere. In Kharkiv carbon monoxide is the substance which exceeds the standards. The level of pollution is characterized by the categories of "clean" "poorly contaminated" atmosphere. In Lviv there were high concentrations of formaldehyde. The level of air 
pollution in Lviv can be categorized as "poorly contaminated". The level of air pollution in Kyiv is characterized by a single category - "contaminated" atmosphere.

- The comparative analysis of the pollution level of the individual IUAs in Ukraine showed that the maximum values of the CAPI are observed in the city of Dnipro. Kyiv ranks second. The minimum level is observed in the city of Kharkiv.

- For the Dnipropetrovsk region the $M_{A B}$ from the stationary sources significantly exceeds that of the mobile ones. For the Kharkiv region, over the years, the load from the stationary sources decreases compared with the mobile ones. The value of the $M_{A B}$ in the Lviv region is generally reduced due to reducing the emissions from the stationary sources. In the Kyiv region, the level of technogenic load from the mobile sources is much higher than that of the stationary ones. In general there is a reduction in the load from both categories of pollution sources.

- For all the IUAs the level of anthropogenic pressure from the stationary sources is an order of magnitude higher than the corresponding one in the regions.

- The maximum load is observed in the Dnipropetrovsk region. Among the IUAs the city of Dnipro also suffers the greatest burden. The cities of Lviv and Kharkiv are characterized by relatively similar values of the $M_{A B}$ indicator. The data obtained for the IUA do not reflect the situation as a whole, since the information about the volumes of the pollutants emissions from the mobile sources is absent.

The obtained results are an extension of the research presented in the work [1]. They are the basis for the further development of the regional programs aimed at reducing technogenic impact on the air. It should be noted that it is necessary to include the data about the volumes of the emissions from the mobile pollution sources both in the regions as a whole and in the cities into the statistical environmental regional reports.

\section{References}

[1] Chugai A., Safranov T., Holik Yu.: International Journal of Engineering \& Technology (UAE), 2018, 7 (4.8), 783.

[2] Bezuhlaia E. Iu. Monytorynh sostoianyia zahriaznenyia atmosferы v horodakh. Lenynhrad: Hydrometeoyzdat, 1986. (in Russia)

[3] Adamenko O. M., Rudko H. I. Ekolohichna heolohiia. Kyiv: Manuskrypt,1997. (in Ukrainian)

[4] Rehionalna dopovid pro stan navkolyshnoho pryrodnoho seredovyshcha v Dnipropetrovskii oblasti za 2016 rik. Dnipro, 2017. (in Ukrainian)
[5] Natsionalna dopovid pro stan navkolyshnoho pryrodnoho seredovyshcha v Ukraini u 2015 rotsi. Kyiv, 2017. (in Ukrainian)

[6] Chugai A. V., Cherniakova O. I., Bazyka Yu. V.: Visnyk Kharkivskoho natsionalnoho universytetu im. V. N. Karazina, Ser. "Ekolohiia", 2018, 19, 75. (in "Ukrainian)

[7] Ekolohichnyi pasport Dnipropetrovskoi oblasti za 2013 rik. Dnipro, 2014. (in Ukrainian)

[8] Ekolohichnyi pasport Dnipropetrovskoi oblasti za 2014 rik. Dnipro, 2015. (in Ukrainian)

[9] Ekolohichnyi pasport Dnipropetrovskoi oblasti za 2015 rik. Dnipro, 2016. (in Ukrainian)

[10] https://www.slideshare.net/DIA_investment/ss87975316.

[11] Ekolohichnyi pasport Dnipropetrovskoi oblasti za 2017 rik. Dnipro, 2018. (in Ukrainian)

[12] Dopovid pro stan navkolyshnoho pryrodnoho seredovyshcha v Kharkivskii oblasti u 2017 rotsi. Kharkiv, 2018. (in Ukrainian)

[13] Rehionalna dopovid pro stan navkolyshnoho pryrodnoho seredovyshcha $\mathrm{v}$ Kharkivskii oblasti za 2013 rik. Kharkiv, 2014. (in Ukrainian)

[14] Ekolohichnyi pasport Kharkivskoi oblasti za 2016 rik. Kharkiv, 2017. (in Ukrainian)

[15] Ekolohichnyi pasport Kharkivskoi oblasti za 2014 rik. Kharkiv, 2015. (in Ukrainian)

[16] Ekolohichnyi pasport Kharkivskoi oblasti za 2015 rik. Kharkiv, 2016. (in Ukrainian)

[17] Ekolohichnyi pasport Kharkivskoi oblasti za 2017 rik. Kharkiv, 2018. (in Ukrainian)

[18] Rehionalna dopovid pro stan navkolyshnoho pryrodnoho seredovyshcha u Lvivskii oblasti v 2013 rotsi. Lviv, 2014. (in Ukrainian)

[19] Rehionalna dopovid pro stan navkolyshnoho pryrodnoho seredovyshcha u Lvivskii oblasti v 2014 rotsi. Lviv, 2015. (in Ukrainian)

[20] Rehionalna dopovid pro stan navkolyshnoho pryrodnoho seredovyshcha u Lvivskii oblasti v 2015 rotsi. Lviv, 2016. (in Ukrainian)

[21] Rehionalna dopovid pro stan navkolyshnoho pryrodnoho seredovyshcha u Lvivskii oblasti v 2016 rotsi. Lviv, 2017. (in Ukrainian)

[22] Ekolohichnyi pasport Lvivskoi oblasti za 2017 rik. Lviv, 2018. (in Ukrainian)

[23] Rehionalna dopovid pro stan navkolyshnoho pryrodnoho seredovyshcha Kyivskoi oblasti u 2017 rotsi. Kyiv, 2018. (in Ukrainian)

[24] http://old.adm.dp.gov.ua/OBLADM/obldp.nsf/ index.pdf.

[25] Bazyka Yu. V., Terlina D. V., Chugai A. V.: Vseukrainska naukova on-line konferentsiia zdobuvachiv vyshchoi osvity i molodykh vchenykh "Suchasni problemy ekolohii", Ukraine, Zhytomyr, 2019, 26. (in Ukrainian)

[26] Ekolohichnyi pasport Kyivskoi oblasti za 2014 rik. Kyiv, 2015. (in Ukrainian) 